\title{
Taxonomic studies of two trifoliate legumes of high economic importance in Ebonyi State, South-eastern Nigeria
}

\author{
O. E. Nwankwo ${ }^{1}$, F. C. Ambrose ${ }^{1}$, S. A. Odewo ${ }^{2}$ and K. Nwanchor ${ }^{3}$ \\ ${ }^{1}$ Department of Applied Biology, Faculty of Science Ebonyi State University, Abakaliki Nigeria \\ ${ }^{2}$ Herbarium unit Forest Research Institute of Nigeria (FRIN), Ibadan Nigeria \\ ${ }^{3}$ Department of Crop Science, Faculty of Agriculture, Ebonyi State University, Abakaliki Nigeria \\ *Corresponding Author: ephraimnwankwo8@gmail.com
}

\begin{abstract}
Taxonomic studies of Sphenostylis stenocarpa and Centrosema pubescens based macro-morphology and foliar epidermises were carried out to determine their similarities and differences. The taxa are of high economic values as they are used as food and medicine in Nigeria. Standard methods were used to carry out the studies as qualitative and quantitative macromorphological characters of the taxa were obtained by visual observation and measuring with metre rule while foliar epidermal study followed standard methods previously used by other researchers. The taxa studied have trifoliate leaf type with leaf and leaflet arrangement alternate and opposite respectively. From the foliar epidermises, Sphenostylis stenocarpa possesses paracytic stomata on the abaxial surface and anisocytic stomata on the adaxial. The abaxial surface of Centrosema pubescens possesses anomocytic and paracytic stomata and anomocytic stomata on the adaxial surface. Cell shapes of the foliar epidermal surfaces are irregular with undulate anticlinal wall patterns except on the adaxial surface of Sphenostylis stenocarpa with pentagonal cell shape and straight anticlinal wall. The two taxa are similar in their leaf type and arrangement but differ greatly in their stomatal types.
\end{abstract}

Keywords: Macromorphology, Taxonomic studies, Stomata, Foliar epidermis, Ebonyi State.

\section{INTRODUCTION}

Sphenostylis stenocarpa (A.Rich.) Harms (commonly known as African Yam Bean) and Centrosema pubescens Benth (commonly known as Centro) belong to the family Fabaceae in the tribes Phaseoleae. Flowers and seeds of Sphenostylis stenocarpa are edible in most West African counties; its root is a source of medicine, dye and fish poison (Potter \& Doyle, 1992). The edible tubers of Sphenostylis stenocarpa are useful in Central and East Africa and it is a cultivated species because of its morphological characteristics different from the wild taxa (Potter \& Doyle, 1992). Centrosema pubescens is a forage crop that grows well in nutrient-poor soils and can tolerate drought because of its deep root system. It is used as green manure in some parts of the tropical regions (Houndjo et al., 2017; Uphof, 1959). Centrosema pubescens is widely used as a plantation cover and pasture legume in Asia, the Pacific Islands, the wet tropics of Australia and indeed much of the humid tropics worldwide because it fixes nitrogen in the soil (http://proseanet.org/)

Both the species are climbing vines with trifoliate leaves and are typically found in Africa (Moteetee \& VanWyk, 2012; Chukwuma et al., 2014). Sphenostylis stenocarpa has dorsiventral flattened styles with wedged shape, glabrous, prostrate and twining features with root tubers in addition to its edible seeds hence, it is placed in the genus Sphenostylis (Moteetee \& VanWyk, 2012) while Centrosema pubescens leaves are pinnately trifoliate; stipules ovate to ovatelanceolate, elliptical, rounded at the base, rounded to acuminate at the apex, dark-green, slightly hairy, especially on the lower surface; flowers pink-mauve or white with purple markings (Chukwuma et al., 2014).

\section{Economic importance of the two taxa}

Sphenostylis stenocarpa is one of the plant species used as food and medicine in west tropical Africa (Popoola et al., 2011). It is a good source of protein and minerals such as phosphorus, potassium and iron (Ajibade et al., 2005). In Ghana, seeds of Sphenostylis stenocarpa were used traditionally for both puberty rite celebration and treatment of stomach aches (Klu et al., 2001). Nwankwo et al. (2018) reported that the seed milk of Sphenostylis stenocarpa could be used to manage diabetes by various ethnic groups, especially Nsukka people in Enugu State, Southeastern Nigeria.

Centrosema pubescens is very useful in the treatment of skin diseases eczema and acne. Leaves of Centrosema pubescens can serve as a cheap source of protein, calcium and potassium for broiler chickens and other animals. It is a cover crop that naturally controls weeds by suppression and improves soil fertility and animal health (Houndjo et al., 2017).

Although Sphenostylis stenocarpa and Centrosema pubescens are not in the same genus, they are in the same tribe 
(Phasoleae) and macro-morphologically look alike. Owing to this macro-morphological similarity, it is important to provide additional characters for their delimitation. Besides, clear and satisfactory epidermal foliar pictures of the taxa especially, Sphenostylis stenocarpa have not been published, hence, the current studies aimed at examining the similarities and differences between the taxa using macro-morphology and foliar epidermises to provide additional diagnostic characters of the taxa for their taxonomy.

\section{MATERIALS AND METHODS}

\section{Sample collection}

Fresh specimens of Sphenostylis stenocarpa and Centrosema pubescens were collected and identified at Ebonyi State University Herbarium, Abakaliki, Nigeria and authenticated at Forest Research Institute of Nigeria (FRIN), Ibadan, Oyo State Nigeria. The voucher specimens with the numbers EBS-H-0339 and EBS-H-0349 respectively were deposited in the herbarium.

\section{Macro-morphological study}

Leaflets' length and width were measured following the method used by Nwankwo \& Ayodele (2017). From each specimen, a total of 10 leaflets were randomly selected and measured. The qualitative and quantitative characters of the taxa were obtained by visual observation and measuring with metre rule respectively.

\section{Foliar epidermal preparation}

The method used by Nwankwo \& Ayodele (2017) was followed. The standard median portions of the leaflets of each specimen were cut with a razor blade and soaked in concentrated trioxonitrate $(\mathrm{v})$ acid $\left(\mathrm{HNO}_{3}\right)$ in well covered Petri dishes for about fifteen minutes to macerate the mesophyll. The presence of bubbles on the soaked specimens indicated their readiness for their separation. The specimens were transferred into clean Petri dishes and adequately rinsed with distilled water, before the abaxial and adaxial layers were separated with a fine Carmel hair brush. Debris on the separated surfaces were carefully cleared off with a fine Carmel hair brush, and the isolated epidermal layers were adequately rinsed in water. The epidermises were then transferred into another Petri dish containing 50\% ethanol for 2 minutes, thereby allowing hardening of the cells. Afterwards, tissues were transferred unto a clear-glass microscopic slide and stained with Safranin for five minutes and then rinsed again in distilled water to remove excess staining. The stained epidemises were mounted in $25 \%$ glycerol on a microscopic slide, covered with coverslips and the edges of the coverslips were ringed with nail varnish to prevent dehydration. Two slides of the adaxial and abaxial surfaces of each of the leaves of the two species were prepared. All slides were labelled appropriately and examined under the Canon light microscope with $\times 40$ objective. Photomicrographic images of each specimen were taken with the Canon digital camera mounted on the Canon photomicroscope at Applied Biology laboratory, Ebonyi State University, Nigeria.

\section{RESULTS}

\section{Taxonomy}

The two taxa studied have trifoliate leaf types with leaf and leaflet arrangement alternate and opposite. Summaries of the results are shown in tables 1 and 2 and presented in figures 1 and 2.

Table 1. Qualitative and quantitative macro-morphological features of Sphenostylis stenocarpa (A.Rich.) Harms and Centrosema pubescens Benth.

\begin{tabular}{lrr}
\hline Characters & Sphenostylis stenocarpa & Centrosema pubescens \\
\hline Leaf type & Trifoliate & Trifoliate \\
Leaflet surface & Glabrous & Pubescent \\
Leaf arrangement & Alternate & Alternate \\
Leaflet arrangement & Opposite & Opposite \\
Leaf margin & Entire & Serrulate \\
Flower colour & Red & Pink, white \\
Average Leaflet length $(\mathrm{cm})$ & 7.45 & 5.32 \\
Average Leaflet width $(\mathrm{cm})$ & 2.97 & 3.45 \\
\hline
\end{tabular}

Table 2. Foliar epidermal features of Sphenostylis stenocarpa (A.Rich.) Harms and Centrosema pubescens Benth.

\begin{tabular}{lrrrr}
\hline Epidermal features & \multicolumn{2}{c}{ Sphenostylis stenocarpa } & \multicolumn{2}{c}{ Centrosema pubescens } \\
\cline { 2 - 5 } & Abaxial surface & Adaxial surface & Abaxial surface & Adaxial surface \\
\hline Stomatal type & Paracytic & Anisocytic & Anomocytic, paracytic & Anomocytic \\
Cell shape & Irregular & Pentagonal & Irregular & Irregular \\
Anticlinal wall patterns & Undulate & Straight & Undulate & Undulate \\
Trichomes & Present & Present & Present & Present \\
\hline
\end{tabular}



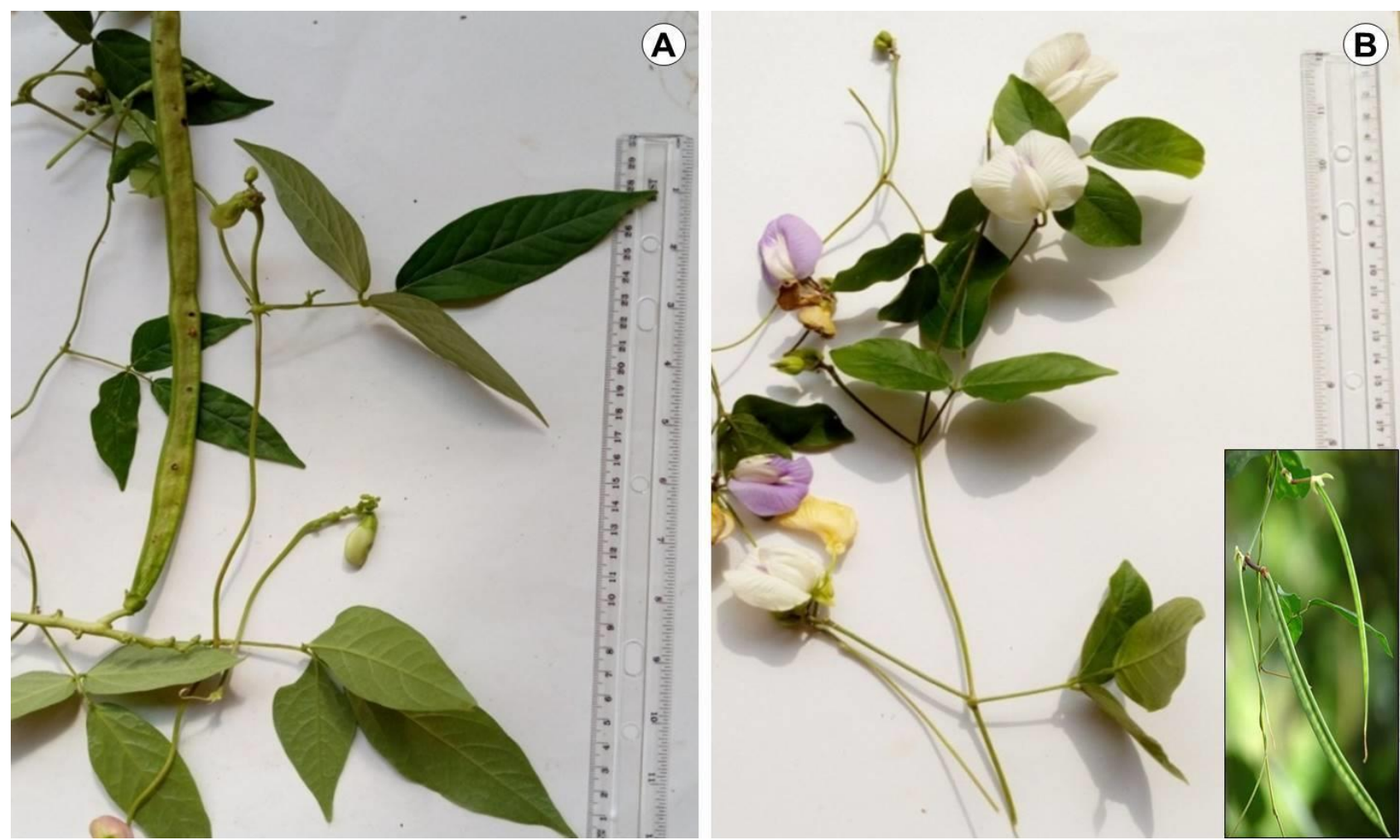

Figure 1. A, Sphenostylis stenocarpa (A.Rich.) Harms - Fruiting twig; B, Centrosema pubescens Benth - Flowering twig (Inset: Fruits).
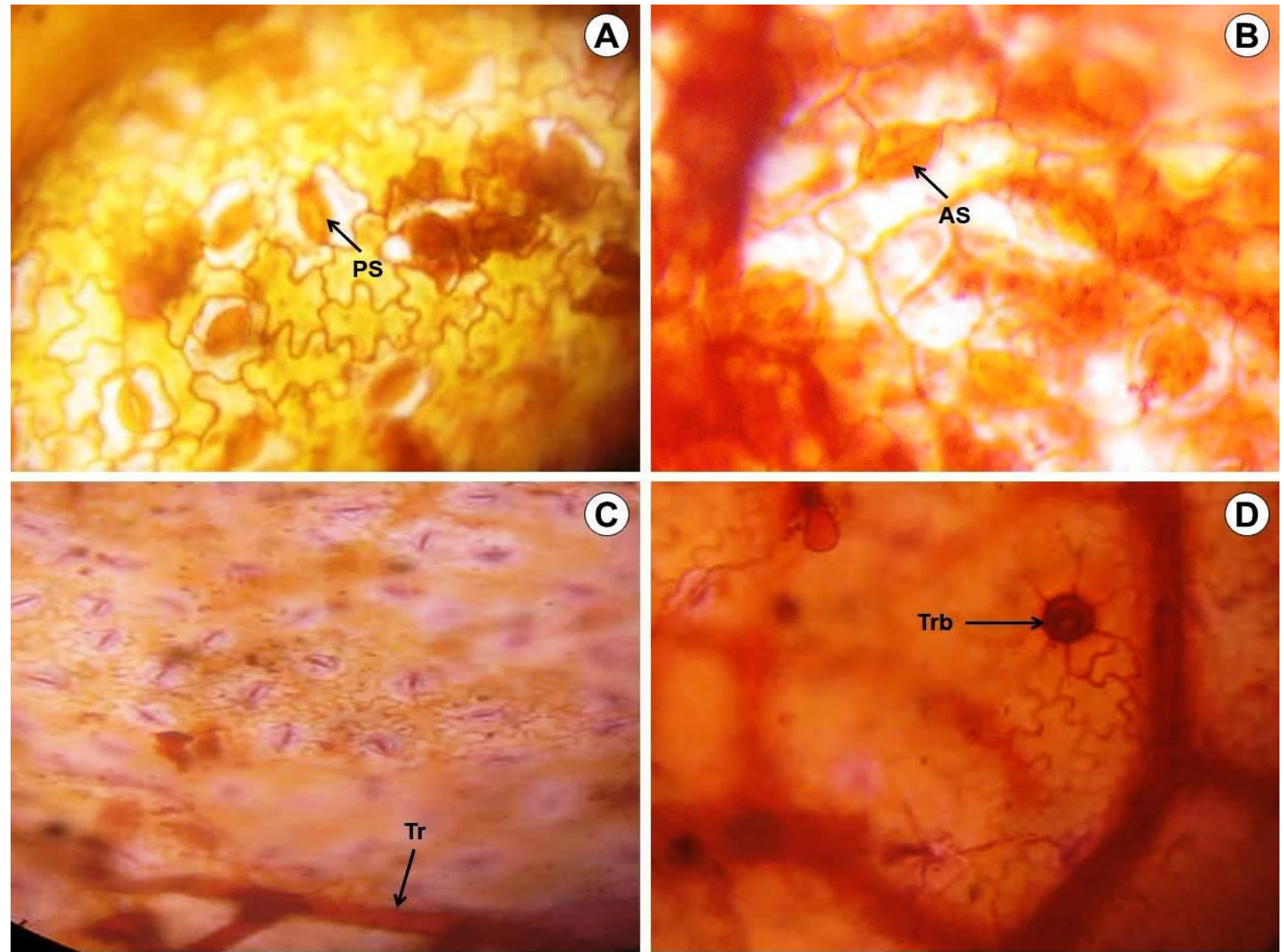

Figure 2. Photomicrographs of the foliar epidermal surfaces of the Legumes studied, where: A, Abaxial surface of Sphenostylis stenocarpa (A.Rich.) Harms showing paracytic stomata; B, Adaxial surface of Sphenostylis stenocarpa showing anisocytic stomata; $\mathbf{C}$, Abaxial surface of Centrosema pubescens Benth showing trichome; D, Adaxial surface of Centrosema pubescens showing trichomes base. [PS- Paracytic Stomata, AS- Anisocytic Stomata, Tr- Trichome, Trb- Trichome base] 


\section{Sphenostylis stenocarpa (A.Rich.) Harms}

Leaflet shape, apex, base and margin are lanceolate, acuminate, acute and entire in Sphenostylis stenocarpa. The flower colour of Sphenostylis sternocarpa is red. From the foliar epidermises, Sphenostylis stenocarpa possesses paracytic stomata on the abaxial surface and anisocytic stomata on the adaxial surface.

\section{Centrosema pubescens Benth.}

The leaflet shape was elliptic with acute apex and base and serrulate margin: leaf surface is pubescent. The standard petal of Centrosema pubescens is pink and white. The abaxial surface of Centrosema pubescens possesses anomocytic and paracytic stomata while anomocytic stomata are common on the adaxial surface.

\section{DISCUSSION}

Results of these analyses showed some diagnostic characters that could be used for taxonomic decisions. According to Stace (1984), macro-morphological characters and foliar epidermal features are very significant in the taxonomy of plants. The stomatal types observed in Sphenostylis stenocarpa which are paracytic and anisocytic on abaxial and adaxial surfaces respectively, partially disagrees with the earlier work of Agbolade et al. (2011), who reported paracytic stomata on both surfaces. The disagreement in our results may be attributed to different environments where the plant samples were collected as Stace (1984) pointed that environment affects the foliar epidermal features. Furthermore, the earlier report of Chukwuma et al. (2014) on foliar epidermal features of Centrosema pubescens is in line with the results of the current studies. The studies made the full macro-morphological description as well as foliar epidermal features available for other prospective researchers. These studies have shown that the plant species analysed, are very similar in their macro-morphological features but differ mostly on their foliar epidermal features. Nevertheless, the presence of leaflet shape: lanceolate, leaflet surface: glabrous, flower colour: red and stomatal types of Sphenostylis stenocarpa can serve as a diagnostic character in distinguishing this species from other trifoliate legumes in the tribe Phaseoleae. The special features of Centrosema pubescens are the leaflet shape: elliptic, flower colour: pink and white as shown in table 1 and figure 1 .

\section{CONCLUSION}

This work supports the earlier studies and reports of amphistomatic leaf epidermises exhibited by members of the Papilionoideae. Macromorphologically, Sphenostylis stenocarpa has a glabrous leaf surface while Centrosema pubescens is hairy. Their stomatal types may be useful in their taxonomy.

\section{ACKNOWLEDGEMENTS}

I sincerely acknowledged my project colleagues, Samuel Adenniyi Odewo, who helped financially and in the authentication of the taxa. The effort of Franklin Chikezie Ambrose and Kelechi Nwanchor who helped in the foliar epidermal study is highly appreciated.

\section{REFERENCES}

Agbolade J.O., Adegbite A.E., Olawuyi O.J., Aina D.A., Popoola, J.O. \& Aremu B.R. (2011). Comparative study on the epidermal features of twelve under-utilized legume accessions. Journal of Agricultural Science, 1(4): 55-61.

Ajibade S.R., Balogun M.O., Afolabi O.O., Ajomole K.O. \& Fasoyiro S.B. (2005). Genetic variation in nutritive and anti-nutritive contents of African yam bean (Sphenostylis stenocarpa). Tropical Science, 45: 144-148.

Chukwuma E.C., Soladoye M.O. \& Abdus Salaam K.R.P. (2014). Taxonomic value of the leaf micro-morphology and quantitative phytochemistry of Clitoria ternatea and Centrosema pubescens (Papilionoideae, Fabaceae). Phytologia Balcanica, 20: (1):3-8.

Houndjo D.B.M., Adjolohoun S., Ahoton L., Basile G.B., Saidou A., Marcel H.M. \& Sinsin, B.A. (2017). Influence of Cow manure and Row spacing on growth, flowering and seed yield of Centro (Centrosema pubescens Benth.) on ferralitic soils of Benin (West Africa). American Journal of Agricultural Research, 2017: 1-12.

Klu, G.Y.P., Amoatey, H.M., Bansa, D. \& Kumaga, F.K. (2001). Cultivation and use of African yam bean (Sphenostylis stenocarpa) in the Volta Region of Ghana. The Journal of Food Technology in Africa, 6: 74-77.

Moteetee A.N. \& VanWyk B.E. (2012). Revision of the genus Sphenostylis (Fabaceae: Phaseoleae) in South Africa and Swaziland. Bothalia, 42(1): 1-6.

Nwankwo M.O., Etim E.E. \& Ogbonna I.I. (2018). Investigation on the Anti-diabetic Activity of Sphenostylis stenocarpa Seed Milk Extract in Alloxan-induced Diabetes Rats. International Journal of Scientific and Research Publications, 8(8): 824-829.

Nwankwo O.E. \& Ayodele A.E. (2017). Taxonomic Studies of the genus Indigofera Linn. in Nigeria. International Digital Organisation Journal for Scientific Research, 2(3): 10-26.

Popoola J.O., Adegbite A.E. \& Obembe O.O. (2011). Cytological studies on some accessions of African yam bean (AYB) (Sphenostylis stenocarpa (Hochst. ex. A. Rich.) Harms). International Research Journal of Plant Science, 2(8): 249-253.

Potter, D. \& Doyle, J.J. (1992). Origins of the African yam bean (Sphenostylis stenocarpa, Leguminosae): Evidence from morphology, isozymes, chloroplast DNA and linguistics. Economic Botany, 46: 276-292. 
Plants and Environment (2021) 3(2): 47-51

Stace C.A. (1984). Cuticular Studies as an Aid to Plant Taxonomy. Bulletin of the British Museum (Natural History) Botany, 4: 1-78. Uphof, J.C.Th. (1959). Dictionary of Economic Plants. Weinheim. 